\title{
Production of Dimethylfuran as Liquid Fuel from Biomass Derived Carbohydrates
}

\author{
Hegde $\mathbf{H}$ and Nitinkumar SS* \\ Department of Chemistry, Manipal Institute of Technology, India
}

Submission: May 4, 2017 Published: June 05, 2017

*Corresponding author: Nitinkumar SS, Department of Chemistry, Manipal Institute of Technology, Karnataka, India, Email: snitinshetty@gmail.com

\section{Introduction}

Diminishing fossil fuel reserves and increasing global warming are the major problems faced by the world now. This demands sustainable sources of energy must resource required energy in the near future. Serious steps to restrict the existing concern and to find alternate energy sources have been the area of interest for the scientific community. On the contrary, our major concern is over availability and costs of petroleum feedstock's, which has given rise to a growing interest in alternative carbon sources such as natural gas, coal, biomass, and shale oil and tar sands. The conversion of renewable resources, such as biomass and organic wastes to conventional liquid and gaseous fuels has been approached from several perspectives. So, in the process, development of more efficient processes for conversion of biomass to liquid fuels, such that the cost of these fuels would be competitive with the cost of fuels derived from petroleum emerged as an important solution for the energy crisis.

For fuels to be useful in the everyday life, they must have specific physical properties that allow for efficient distribution, storage and combustion. Non-renewable petroleum-derived liquid fuels are currently fulfilling by these properties. But, Ethanol is the only renewable liquid fuel currently produced in large quantities which suffers from several limitations, including low energy density, high volatility, and contamination by the absorption of water from the atmosphere. However, development of 2,5-dimethyl furan as an efficient liquid fuel has attracted major attention in the field of energy due to their advantage over ethanol. i.e. high energy density, high boiling point and non-solubility in water. Here, we review different catalytic strategies for the production of 2,5-dimethylfuran from fructose (a carbohydrate obtained directly from biomass or by the isomerization of glucose) for use as a liquid transportation fuel.
Furfural aldehyde and its derivatives so produced from biomass conversion have generally had limited uses in the past. However, one potentially important use is in the production of furan and its various derivatives which have significant prospective as octane enhancers and boosters in various gasoline blends. In particular, methylated furans like 2,5-dimethylfuran (DMF) have particularly high blending octane numbers making them especially useful and economic products. The other most important intermediate formed from further processed furfural aldehydes where the hexose dehydration product, the platform chemical 5-hydroxymethylfurfural (HMF) are obtained employed in the manufacturing of lysine, vitamin C, plastics, and many furantype resins. It can also be used as a solvent, lubricant, dispersing agent, and plasticizer. HMF can easily under goes condensation with ketones (e.g., acetone), followed by hydrodeoxygenation resulting in the formation of $\mathrm{C} 9$ to $\mathrm{C} 15$ alkanes which are used in diesel and jet fuels [1-3].

\section{Significance and Recent Trends of the Work}

In general, the conversion of biomass to HMF and derivatives to furan and its counterpart derivatives has been achieved utilizing a variety of existing processes. These processes include a variety of catalytic techniques which, unfortunately, have several drawbacks related to environmental hazards. In particular, these techniques generally utilize a transition or noble metal catalyst which either produces low yields of furan derivatives or is highly expensive to use due to either the high cost of obtaining the catalyst or of rejuvenating the catalyst of reuse. The first step involves the acid-catalysed dehydration of fructose to produce HMF in a biphasic reactor. Because the normal boiling point of HMF is too high for it to be used as a fuel, the HMF extracted by the organic phase of the biphasic reactor is subsequently converted to DMF by hydrogenolysis of $\mathrm{C}-\mathrm{O}$ bonds over a copper-ruthenium $(\mathrm{Cu}-\mathrm{Ru})$ catalyst (Figure 1). 


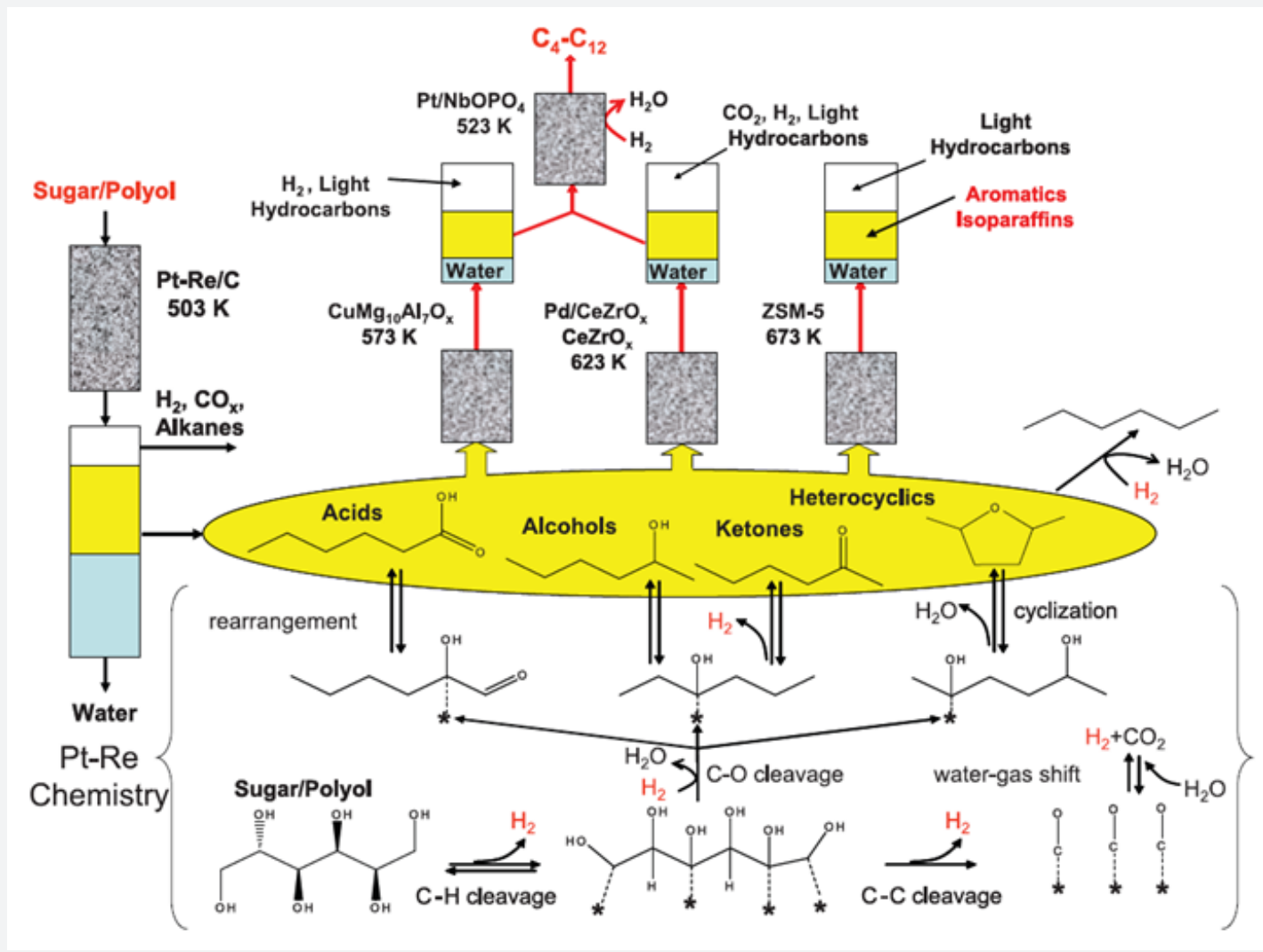

Figure 1: Generation of mono functional organic compounds from catalytic processing [5].

If we basically looking into the biomass the conversion basically is by three methods [4]

1. Gasification resulting in formation of syngas $(\mathrm{CO}+\mathrm{H} 2)$ which further can be uses in FT or WGS for further applications.

2. Pyrolysis for production of biooils

3. Hydrolysis leading to formation of sugars and lignin which can be used by various chemical transformations to obtain wide range of chemicals

The scheme below depicts the generation of mono functional organic compounds from catalytic processing of primary biomass-derived reactants sorbitol or glucose, providing a platform for the production of liquid transportation fuels [5].

As we use easier available raw material such as glucose, the efficiency of large-scale production of DMF from biomass would improve. Although few achieved moderate revenue from HMF immediately from glucose, the conversion of fructose is more selective. In this regard, efficient processes already exist in the Production of high amounts of glucose fructose, such as enzyme catalyzed Isomerization combined with a simulated moving bed separation [6,7]. While challenges remain for commercial application, Research in this direction opens a new path for DMF production as one biomass-derived liquid transport fuel.

\section{References}

1. Huber W, Iborra S, Corma A (2006) Synthesis of transportation fuels from biomass: chemistry, catalysts, and engineering. Chem Rev 106(9): 4044-4098.

2. Chheda JN, Dumesic JA (2007) an overview of dehydration, aldolcondensation and hydrogenation processes for production of liquid alkanes from biomass-derived carbohydrates. Catalysis Today 123(2007): 59-70.

3. Yong G, Zhang Y, Ying JY (2008) Efficient catalytic system for the selective production of 5-hydroxymethylfurfural from glucose and fructose. Angew Chem Int Ed Engl 47(48): 9345-9348.

4. Serrano-Ruiz JC, West RM, Dumesic JA (2010) Catalytic conversion of renewable biomass resources to fuels and chemicals. Annu Rev Chem Biomol Eng 1: 79-100.

5. Kunkes EL, Simonetti DA, West RM, Serrano-Ruiz JC, Gärtner CA (2008) Catalytic conversion of biomass to mono functional hydrocarbons and targeted liquid-fuel classes. Science 322(5900): 417- 421.

6. Broughton B, Gerhold CG (1961) US Patent US2985589.

7. Hashimoto K, Adachi S, Shirai Y (1993) In: Ganestos G \& Barker PE (Eds.), Preparative and Production Scale Chromatography. CRC Publishing, New York, USA, pp. 395-417. 
This work is licensed under Creative

Commons Attribution 4.0 Licens

DOI: 10.19080/RAPSCI.2017.01.555565
Your next submission with Juniper Publishers will reach you the below assets

- Quality Editorial service

- Swift Peer Review

- Reprints availability

- E-prints Service

- Manuscript Podcast for convenient understanding

- Global attainment for your research

- Manuscript accessibility in different formats

( Pdf, E-pub, Full Text, Audio)

- Unceasing customer service

Track the below URL for one-step submission https://juniperpublishers.com/online-submission.php 